\title{
DIE IMPLIKASIES VAN ARTIKEL 2 (1) (a) VAN DIE WET OP DIE NASIONALE ONDERWYSBELEID, 1967
}

\section{Inleiding}

Op 31 Maart 1967 is die veelbesproke Wet op die Nasionale Onderwysbeleid, 1967 gepromulgeer. Daar is 'n raamwerk van tien beginsels neergelê wat onder meer handel oor sake soos Christelike karakter, nasionale karakter, moedertaalonderwys, die plek van die ouergemeenskap, vry onderwys, koördinasie op nasionale grondslag van leerplanne en kursusse, ens.

Voorop in die lys van beginsels is die beginsel (soos vervat in art. 2 (i) (a)) dat ,die onderwys in skole wat deur 'n Staatsdepartement (met inbegrip van 'n provinsiale administrasie) in stand gehou, bestuur en beheer word, 'n Christelike karakter moet hê, maar dat die geloofsoortuiging van die ouers en die leerlinge geëerbiedig moet word wat betref godsdiensonderrig en godsdienstige plegtighede".

(Hierdie bespreking gaan slegs oor die implikasies van hierdie bepaling vir die openbare onderwys in sy huidige vorm en raak nie die beginsel van ouerskole eksplisiet nie.)

\section{Die beginsel}

Die vraag kan nou met reg gestel word of dit 'n suiwer beginsel is, en verder of dit wenslik is om sodanige beginsel neer te lê in die onderwys van 'n bevolking met so 'n heterogene geloofsaard en oortuiging. Die skakeringe is veelvuldig tussen die grense van geloof en ongeloof. Het ons nie hier te doen met die diepste roersele van die siel en met 'n hoeksteen van lewens- en wêreldbeskouing nie? Dit raak nie die oppervlak nie, maar tref tot in die wese van menswees. Is dit demokraties om ' $n$ hele bevolking hieraan te onderwerp? Is dit dan nie 'n erkende begrip dat die skool daarop bereken is om onderrig en kundighede en 'n mate van breër opvoeding te verskaf en dat die meer spesifieke opvoedkundige aangeleenthede soos gesinsverhoudinge, geslagsvoorligting en godsdienstige opvoeding in die intiemer huislike milieu sal geskied nie? (Wat die godsdiensonderrig betref, sal die kerk ook 'n kardinale plek inneem.) Die hiper-demokrasie, die V.S.A., het byvoorbeeld 
hierdie knoop deurgehak deur die godsdienstige opvoeding en godsdienstige verrigtinge en die godsdienstige karakter uit die openbare skool te weer. Die skool kan dan 'n ware volkskool wees (Horace Mann se ideaal van die "common school") waarin alle lae en gesindtes tuis kan wees. Huis en kerk kan dan die godsdienstige opvoeding behartig, maar nie die skool nie.

Ons kan egter nie met laasgenoemde reëling in 'n oorwegend Christelike gemeenskap saamstem nie. In die eerste plek, wat die maatskaplike oorweging betref, is die skool tog 'n aanvulling en in hoë mate ' $n$ verlengstuk van die huislike opvoeding, alhoewel in aard verskillend. Dit vorm die brug tussen die (Christelike) huisgesin en die (Christelike) samelewing. Gesien teen die eenheidsbeeld huis-skool-gemeenskap kan die een komponent tog nie totaal anders as die ander twee wees nie, veral nie ten opsigte van die allerbelangrikste aspek van menswees nie. In die tweede plek is daar die opvoedkundige oorweging wat absoluut ondubbelsinnig is en wat tans deur alle moderne opvoedkundiges erken en beklemtoon word, nl. dat die totaliteit van die mens in ag geneem moet word. Al die aspekte en nuanses, behoeftes en aard moet in berekening gebring word, sodat die kind gebalanseerd en volledig tot volwaardige persoon kan gedy. Sny nou die religieuse strewe met al sy newe-effekte en implikasies uit die skoolopvoeding weg, en jy bly sit met ' $n$ holle, oppervlakkige, bloot nuttigheidsonderwys en opvoeding. Daar is ook 'n derde oorweging, $\mathrm{nl}$. die religieuse. God eis die ganse lewe en bestaan van die mens op. Geen Christengelowige kan sonder siddering toesien nie dat twaalf lewensjare (tot matriek), wat so grootliks deur binneen buiteskoolse bedrywighede oorheers word, leeg, sonder kennis, liefde en diens van God moet vergly en 'n verminkte volwassene oplewer. Dit sou volslae ongehoorsaamheid aan die bevel van God beteken.

Anders gesien, beteken 'n „demokratiese" reëling soos dié in die V.S.A. nie neutraliteit nie? Daar kan teoreties wel sprake wees van neutraliteit ten opsigte van verskillende kerklike dogmas deur uitskakeling daarvan so ver prakties moontlik, of deur slegs algemeen aanvaardes in byvoorbeeld 'n Protestantse gemeenskap van verskillende kerkverband te behou. Waar dit gelowiges en ongelowiges raak is dit egter eenvoudig "vir" of „teen”. Maak jy voorsiening vir die behoeftes van gelowiges 
se kinders (wat die meerderheid uitmaak), wek jy die onwil van die ongelowiges. Skakel jy godsdienstige opvoeding uit om neutraal te probeer wees, beteken dit niks minder nie as om die ongelowiges (die minderheid) hartlik te ondersteun. Dit sal dus geen konsiliasiebeleid wees nie, maar die invoer van 'n God-negerende onderwys

Van watter kant ons dit bekyk, is dit die regte ding en hoogs noodsaaklik dat voorsiening vir die religieuse in die skoolopvoeding gemaak word.

\section{Die posisie in die provinsies}

In al die provinsies is daar dus besluit op godsdiensonderrig as skoolvak. Elke Departement het sy eie reëling. Ek verwys slegs na Natal en Transvaal. In die Onderwysordonnansie van Natal No. 23 van 1942 word in art. 13 onder meer bepaal dat leerlinge wie se ouers hulle aan die godsdiensonderrig wil onttrek dit mag doen by wyse van skriftelike reëlings met die skoolhoof. Hierdie "gewetensklousule" is noodsaaklik en is ook van toepassing by die ander provinsies. Onderrigtyd in die vak word nie in die ordonnansie bepaal nie. By wyse van regulasie is dit egter vasgestel op minstens $1 \frac{1}{2}$ uur per week (insluitende opening) van klas I tot st. VI en op 2 periodes van 40 minute elk per week (opening uitgeslote) van st. VII tot $\mathrm{X}$.

Onderrigtyd in Transvaal is by ordonnansie soos volg vasgestel: in laer skole minstens twee uur per week en in middelbare skole minstens een uur per week. Besonder interessant is die bepaling vervat in punt 6 van art. 53 van die Ordonnansie van 1953 , wat dit as vereiste aan alle onderwysers stel om sonder gewetensbeswaar godsdiensonderrig te gee, behalwe diegene wat besware teen die gee van sodanige onderrig aan die Direkteur voorlê. Hier word 'n Christelike gesindheid dus as reël veronderstel. Die implikasies vir onderwysersopleiding is duidelik. Die Natalse Ordonnansie bevat egter geen sodanige bepaling nie.

Besonder veelbetekenend is die dogmaklousule in subartikel 4 vervat. Dit is totaal anders in vorm, inhoud en implikasie as dié van Natal. Waar laasgenoemde alle dogma verbied wat, op die keper beskou, 'n onmoontlikheid is, verbied die Transvaalse bepaling dit nie implisiet nie en laat sekere dogma wel 
toe. Artikel 13 (3) van die Natalse Onderwys-ordonnansie lui: „Geen leerstelling of dogma wat aan enige godsdiens of sekte eie is mag gedurende skoolure in 'n staatskool gedoseer word nie”. Die Transvaalse bepaling lui: „Geen bepaalde leer of dogma wat onderskeidend is van 'n besondere gesindte of sekte, mag in enige openbare skool gedoseer word nie". Met ander woorde, leer of dogma wat nie onderskeidend van 'n besondere gesindte of sekte is nie, mag wel gedoseer word. Ter stawing hiervan is 'n aanhaling uit die Handboek van instruksies vir die leiding van hoofde van skole by die Godsdiensklousule van die Ordonnansie in die Leergang vir Godsdiensonderrig (in Handboek van Leergange vir die Laerskool, 1964, p. 14) oorgedruk. As toeligting tot die dogmabepaling lui dit: „Die inhoud van godsdiensonderrig in laer- en middelbare skole kan ooreenkomstig die bepalings van die Onderwysordonnansie onder andere die volgende behels:

(i) Bybelkennis

(ii) Die Tien Gebooie

(iii) Die Twaalf Artikels (geloofsbelydenis)

(iv) Die Onse Vader".

In punte (ii) tot (iv) is feitlik alle algemene leerstellinge van die Protestantse geloof (meer bepaald die Calvinistiese vertolking) saamgevat. Dit, soos ons weet, vorm die inhoud van die Heidelbergse Kategismus, en hierop is 'n leergang vir die middelbare skool deur die Interkerklike Komitee van die drie Afrikaanse kerke uitgewerk wat as alternatiewe leergang deur die Departement aanvaar is en in die meeste skole gebruik word. Die Interkerklike Komitee het dan ook reeds toeligtende handboeke vir 'n paar standerds voltooi en gepubliseer.

Daar is dus ' $n$ aanmerklike verskil in benadering van godsdiensonderrig by die twee provinsiale onderwysdepartemente. Verder laat geen van beide hom uit oor 'n Christelike karakter in die onderwys nie. Die Oranje-Vrystaat is die enigste wat by wyse van ordonnansie 'n beleidsbepaling in dié verband gedoen het. Erkenning, openbaring en bevordering van die Christelike beginsel in die onderwys word alhier beoog.

Die Nasionale Buro vir Opvoedkundige en Maatskaplike Navorsing het in sy lywige verslag (Navorsingsreeks $\mathrm{Nr}$. 7) duidelike bewyse gevind dat opleidingsinrigtings en departemente geen ooreenstemming ten opsigte van doelstelling by die 
opleiding van onderwysers het nie. Slegs 4 uit die 18 wat op die vraelys gereageer het, het melding van die religieuse doelstelling gemaak.

Dit was dus hoogs nodig vir die Minister van Nasionale Opvoeding om helderheid en eenheid van siening omtrent hierdie kardinale punt te bring. Met inagneming van die feit dat die oorgrote meerderheid blankes in Suid-Afrika die Christelike geloof toegedaan is, met inagneming van die feit dat die Suid-Afrikaanse nasie in die Grondwet as 'n Christennasie erken word, met erkenning van die intense verwikkeldheid van leer en lewe by veral die Afrikanervolk (gesien herkoms - Geus en Hugenoot - Jan van Riebeeck se deklarasie en optrede, die Voortrekkers, die Christelik-nasionale onderwysstelsel in die voormalige Republieke) en die begeerte om die volkslewe en individuele lewe nie van die geloofswortel af te sny nie, ook nie in die skool nie, en met inagneming van die gelowige se roeping om sy kind op te voed in die vrees van die Here, in kennis, liefde en diens tot verheerliking van sy Naam, het die wetgewers wyslik besluit om die godsdiensbepaling voorop te stel in die Wet op die Nasionale Onderwysbeleid.

\section{Vertolking van die artikel}

Die artikel (woordelik in die inleiding van hierdie uiteensetting weergegee) is bindend vir die hele land, ook vir provinsiale onderwysdepartemente. Dit dui dus 'n nasionale koers aan en weier om die onderwys tot ,neutraliteit" te laat verval. Terselfdertyd wil dit geen gewetensdwang uitoefen nie, en bepaal dat die geloofsoortuiging van die ouers en die leerlinge geëerbiedig moet word. Dit maak verder voorsiening vir (by wyse van verwysing na) godsdiensonderrig en godsdienstige plegtighede.

Tot dusver vind ons nog niks nuuts wat afwyk van bestaande gebruike by al die onderwysdepartemente nie. Beteken dit nou dat elke provinsie nog maar soos voorheen sy eie vertolking en toepassing van godsdiensonderrig sal bied? Ons het reeds op uiteenlopendheid gewys. Lees ons egter subartikel $(g)$ hiermee saam, wil dit voorkom asof daar 'n veel groter eenheidsiening sal kom. Die bepaling lui dat daar koördinasie op nasionale grondslag van, onder meer, leerplanne bewerkstellig 
moet word. Dit is dus te verwag dat samesprekings op interprovinsiale vlak sal plaasvind. Indien dit nie deur hoër instansies gereël word nie, is dit sekerlik ander belangstellendes se plig om sodanige besinning en samespreking te versoek. Daar is vir my egter 'n onmisbare voorwaarde aan hierdie reëling verbonde. Die doel moet nie wees om 'n vaal gemiddelde te bewerkstellig om betrokke instansies min of meer tevrede te stel nie, maar om optimum-doeltreffendheid te verkry. Ons soek diepgang, nie konsiliasie nie. Na my persoonlike oordeel bied die Transvaalse stelsel, na baie jare van diepe studie en bemoeiing van Departement, studiekomitees in Interkerklike Komitee, 'n pragtige voorbeeld van wat bereik kan word - op papier altans. Ek beweer nie dat almal hierdie leergange en reëlings klakkeloos moet oorneem nie, maar die koördinering moet lê op die weg van soeke na die hoogs moontlike kwaliteit en nie na 'n gemiddelde nie. As Transvaal se stelsel en inhoud byvoorbeeld naby aan eersgenoemde ideaal kom, moet die ander nader daaraan kom, en nie verwag word dat sy stelsel verdun word nie. Ons is nie hier met 'n kennisvak in die enger sin gemoeid nie, maar met 'n unieke vormingsvak in Goddelike opdrag, een met ewigheidsbetekenis.

Die klousule bring egter iets nuuts op nasionale vlak. Dit is in ooreenstemming met die Vrystaatse bepaling en onder meer die bepaling vervat in die Z.A.R.-wette van 1882 en 1892 . Dit eis 'n Christelike karakter vir die skoolonderrig in die algemeen. Dit was lankal ' $n$ beredeneringspunt dat ons in die onderwys slegs met die godsdiensonderrig volstaan. Net so min as wat Sondag die enigste dag van die week is waarop godsdiensbetragting moet plaasvind, is die godsdiensonderrigperiode die enigste periode waarop die Christelike beginsels ingeskerp moet word. Leer en lewe kan en mag nie geskei word nie. 'n Christen mag nie slegs gedurende 'n kompartementeel-afgeslote tydjie amptelik Christen wees nie. Dit wek 'n dualisme by die kind en 'n besef dat hierdie beginsels slegs vir sekere tye en geleenthede gebêre word. Veral in hierdie tyd van normloosheid en verwildering is die rigsnoere van die geloof van die uiterste betekenis. Hier, in die sekulêre sfeer, is juis die kunstige geleentheid vir die praktiese toepassing van die geloofsbeginsels om aan die algemene onderwys inderdaad 'n Christelike karakter te verleen. Daarom is ons so dankbaar vir 
hierdie rigsnoer wat, indien opgevolg, 'n kosbare identiteit aan ons nasionale onderwys kan verleen. Die uitvoering van die bepaling en kontrolering daarvan is egter 'n moeilike saak en berus grootliks op die visie, geesdrif, toewyding en inisiatief van elke onderwyser.

Elke onderwyser of dosent het in die verlede iets meer of minder of niks in hierdie verband gedoen. Nou word dit 'n vereiste, of ten minste 'n beroep deur die hoogste gesag in die land. Daar kan enersyds 'n algemene verbetering en verdieping bewerkstellig word, waarby diegene betrokke raak wat voorheen nie onwillig was nie, maar nou daartoe aangemoedig word. Andersyds vind diegene wat reeds in die verlede die Christelike karakter in die onderwys en algemene skoolaangeleenthede probeer indra het, nou amptelike goedkeuring en aanmoediging Daarom was dit nodig om hierdie bepaling op die wetboek te plaas - skriftelik, formeel, amptelik.

\section{Implikasies}

(a) Skool en onderwysers: Soos reeds gestel plaas die wetsbepaling bepaalde verantwoordelikhede op die leerplansamestellers en die onderwysowerhede. Diepgang moet nagestreef en koördinasie bewerkstellig word. Dit berus vervolgens op die onderwysers om hulle te wapen met kennis ten opsigte van inhoud en metode om reg aan hierdie unieke opvoedingsmiddel te laat geskied. Vanselfsprekend het ook elke opleidingsinrigting ' $n$ besondere voorbereidingstaak in hierdie verband. Van net soveel belang is dat die res van die skoolonderrig en aanverwante bedrywighede in die lig van Gods Woord gesien en beoefen moet word. Die gulde bindingsdraad van die Evangelie moet sigbaar deureengestrengel wees om 'n verantwoordelikheidsin, roepingsbewustheid, eindbestemmingsbewustheid en 'n gevoel van geborgenheid te bied in 'n wêreld wat sy norme en lewensankers kwytgeraak het. Die koördinerende, kontrolerende en leidende rol van die skoolhoof kan nooit te veel benadruk word nie.

(b) Huis en ouers: Subartikel 2 (1) (b) ken 'n duidelike plek aan die ouergemeenskap toe. Dit is noodsaaklik dat die band tussen huis en skool herstel moet word. Of daar vir die totstandkoming van differensiasie op grond van lewens- en wê- 
reldbeskouing, dit wil sê skole vir kinders van enersgesinde ouergroepe geywer word, en of ingeskakel word by die bestaande skoolstelsel, die noodsaaklikheid staan voorop dat ouers meer belang moet stel in wat in die skool aangaan, veral ten opsigte van die gehalte en leer van die godsdiensonderrig, en of daar duidelike tekens is van die uitgroei van 'n onmiskenbare Christelike karakter in 'n skool. Ouers kan georganiseerd, deur hul reg by die stembus druk op Provinsiale Raadslede uitoefen om kragdadig te ywer vir onderwys gegrond op die Christelike beginsel waar 'n provinsie nie genoeg hieraan doen nie. Ouers kan deur middel van hul skoolkomitees toesien dat mense met 'n positief-Christelike gesindheid en lewenswandel in onderwysposte benoem word. Ouers kan in georganiseerde verband met skoolhoofde skakel oor die gehalte van die godsdiensonderrig en Christelike karakter in die onderwys. Ek veronderstel dat geen skoolhoof, as hy in die regte gesindheid genader word, beswaar sal hê om teenoor ouerrade of skoolkomitees verslag te doen van sy beheer oor hierdie aangeleentheid nie, byvoorbeeld op welke wyse die Christelike karakter doelbewus en opsetlik uitgebou word byvoorbeeld in die uitwerk van werkskemas en hoe skemas en lesvoorbereiding van onderwysers 'n weerspieëling is van wat binne 'n klaskamer te wagte kan wees. Ons weet almal dat opsetlike besinning oor hierdie aspek by die lesvoorbereiding en werkskema 'n handeling ontketen wat andersins sluimerend sou gebly het.

Dit is egter foutief om te reken dat die ouer se taak by die daadwerklike, positief-konstruktiewe bemoeiing by die skool ophou. Ouers mag nie tevrede agteroorsit omdat die skool dan nou (hopelik) goeie werk doen nie. Nou moet daar weer eens en met groter erns met die huisopvoeding en die kerklik-kategetiese bedrywighede voortgegaan word. Kan die ouers met reg verwag dat die skool sy sake moet reghou as die belangrikste deel van die opvoeding, tuis, verwaarloos word? Hoe staan dit met die huiskatkisasie en godsdienstige verrigtinge en die kerkbesoek? Hoe staan dit met die Christelike karakter in die huis (weg van die huisgodsdiens)? Is daar die doelbewuste voorligting (en voorbeeld!) ten opsigte van die Christelike beginsel by ontspanning en sosiale verkeer? Word die vormingsgesprekke oor die praktiese toepassing van hierdie beginsel in lewe en werk gereeld gevoer? 
As ouers reken dat die skool hoofsaaklik die doelbewuste Christelike opvoeding moet waarneem, is dit ' $n$ totale wanbegrip van die skool se taak en van die huis se plek. As ouers verder bemoeiing met die skool maak om daar'n beter gehalte opvoeding te bekom, en die inskerping van die Christelike beginsels en die godsdiensoefening tuis verwaarloos, is dit niks anders as huigelary en bemoeisiekheid nie.

Die kind mag nie blootgestel word aan dualisme nie, nie wat betref vrome godsdiensverrigtinge afgewissel met godsdienslose lewenspraktyk nie, ook nie wat betref 'n Christelike opvoeding tuis en 'n skoolopvoeding sonder ' $n$ onmiskenbare Christelike karakter nie, of omgekeerd, wat 'n dikwels waarneembare en uiters bedroewende verskynsel is.

Die religieuse bepaling in die Wet spreek eksplisiet tot die skool, en implisiet tot die huis. Elke mens met insig weet dat alleen wanneer huis en skool mekaar aanvul, in lyn lê, aktief en berekenend en koöperatief werk, kan die kind werklik, onder die seën van die Here ontwikkel tot volwaardige persoon, die volkome mens van God wat tot elke goeie werk volkome toegerus is.

Soos dit in die Wet op die Nasionale Onderwysbeleid formeel beskryf is, is die religieuse bepaling van groot betekenis. Die ware betekenis dring egter eers tot jou deur wanneer die volle implikasies deurdink word, veral gesien in samehang met ander bepalings van die Wet en die besondere taak van die ouers in hierdie verband.

Universiteitskollege, Durban.

Johann Bekker. 